塞となるためである。

(ii) $\mathrm{CaO}$ が比較的低湿合率 $(2.2 \%)$ な場合は, $\mathrm{Fe}_{2} \mathrm{O}_{3}$ 量には関係なく $\mathrm{SiO}_{2}$ 混合率 $6 \%$ 以上飞なると消化に 対して不安定になる。

(iii）消化增量率変化飞消化試料の外観変化とは一 般に平行するが，常に平行とは限らない。すなわち， 前者江化学反応江基き，後者は物理的変化江基くため であり，かつクリンカー微組織内の通気構造は前者で 一方的働き，後者では可逆的作用するためである。 な拓, 消化後の外観変化とクリンカー内の異方体の存 在状態との間に滛関はない。

（iv）消化增量率，収縮率， $\mathrm{MgO}$ 結晶の大きさの 3 者間には一般に一定関係を示さない。ただし，他成分 を少量にから一定に报き，一成分だけを過剩内変化
するときは一方的の系䖻的関係を示す。

(v) $\mathrm{CaO}, \mathrm{SiO}_{2}, \mathrm{Fe}_{2} \mathrm{O}_{3}$ 含有 マグネシア・クリンカ 一で，卡の酎消化性を決定するものは分析的組成率で はなく，MgO 核対する混合率とその相互比率であ る。
文献
1) 著者, 千葉大学工学部研究報告, 3,5 p.76 87 (1952)
2)永井彰一郎, 墨協;48 424 (1940); 49 149(1941) $50269(1942) ; 5122(1943)$
3）田中・高木，䕓協，50 262(1942)
4）三田・西田・小畑，弿協，50 附 157(1942)
5）近藤・吉田，墨協， $41353(1933)$
6）三田・西田・星，军協， $51460(1943)$
7) 著著, 弿協, 60 17,185(1952)

$(12 / 3 / 53$ 受付 $)$

\title{
マグネシア・クリンカーの熱衝撃抵抗
}

\author{
茂木今朝 吉 \\ (千葉大学工学部)
}

\section{On the Spalling Resistance of the Magnesia Clinker}

By Kesakichi MOTEKI

(Faculty of Technology, Chiba University)

\begin{abstract}
緒
言

マグネシア耐火物は従来熱酎撃に対して弱いものと 云われ，その重要な欠点として挙げられている。そし て，その最大原因をなすものはマグネシア結晶自身の 膨脹係数が大きいためと考光られている。從来マグネ シア耐灭物の熱衝摮佂関する研究は多少なされている が，マグネシア・クリンカー自体の熱衝撃汇関する研 究は余り行方れていない。著者は前報1飞引続いて表 題の測定を行い $\mathrm{CaO}, \mathrm{SiO}_{2}, \mathrm{Fe}_{2} \mathrm{O}_{3} 3$ 成分の存在飞 よる熱衝擊化対する影響を調べた結果沉つて報告す る。マグネシア耐火物の化学悢成と熱衝擊抵捥との関 係関する研究も比較的少なく, わが国では近藤・ 吉田 ${ }^{2)}$ の研究がある, マグネシア・クリンカーそれ自 体の熱衛撃を求めるととは,実際にはマグネシア䐈瓦, マグネシア質耐火物に和ける程, 重要なすのではない と考克るが，マグネシア質酎冰物の基礎研究として， またマグネシア煉瓦構成の基檚材料の性能を熟知する 上にる，一応探究すべきものと考えて央験を行った。
\end{abstract}

\section{I. 実 驗 要 旨}

烃成操作までの研究方針，目的，実験計画などの詳
細は既報》に述べたところと同様であるから省略す

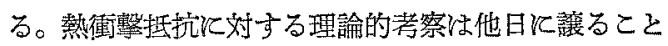
とし, 測定方法についてる種々の提案があるが, 著者 の供陚体は既述の諸報告飞示したようと, 極めて形が 小さいため, 便宜上次項のような定性的な急熱, 急冷 回数を測ることとし，結果は䐲然とするために等高線 形式図形に集約することとした。

\section{II. 実・験 方 法}

使用原料はマグネサイト軽焼物の 2 種，すなかち $\mathrm{CaO} 4.1 \%$ 含有の $\mathrm{M}_{\text {口 }}$ 和よび $\mathrm{CaO} 2.2 \%$ 含有の $\mathrm{M}$ 、を用い，配合剂は化学純 $\mathrm{SiO}_{2}, \mathrm{Fe}_{2} \mathrm{O}_{3}$ またはこ れらを合有する天然鉱を用い，配合基準はクリンカー 中の MgO 分飞対する百分率をるってし，配合範囲は マグネシア・クリンカーの研究という立場から配合剤 の添加量の合計が約 12\% 以下にした（詳細は既報》 そ記述してある)。供試体の製作，焼成などる既報行 詳述したので省略する。ただ, 焼成温度は $1500^{\circ} \mathrm{C}$, 保 特時間 $3 \mathrm{hr}$.である。熱德擊抵抗の測定方法は, まず 急冷用液体として油類を選んだ。水では消化作用が加 わるので，熱㣫撃抵抗だけを測るには不適当と考えた 
からである(もっとも, 高温から 1 回の水中投下位で はクリンカーの消化程度は極めて微弱なものである が, 急冷回数の増加によってての影響は加重される招 それがある。

次飞約 $2 \mathrm{~cm} \phi \times 2 \mathrm{~cm}$ 大の焼成供試体全体を, 常温 より子め $1150^{\circ} \mathrm{C} \pm 10^{\circ} \mathrm{C}$ 飞保持した電気师内で急熱 し，30 分間赫き，ただちに常温の油中没下急冷し， 5 分後取り出し，油を良くぬぐった後ガス小焰中で残 油を焼成除去し，冷却後再び電気师中に投入し，この 操作を試料が割れるまで繰返した。すなわち，供試体 は常温 $\rightarrow 1150^{\circ} \mathrm{C}$ 飞急熱 $\rightarrow$ 常温油中飞急冷 $\rightarrow$ ガス 小焰 で低温急熱 $\rightarrow$ 常温, の過程を循環するととになる。記 録の便宜上, $1150^{\circ} \mathrm{C}$ 急熱を 1 回,油中急冷を 1 回と数 壳て熱衝撃抵抗值とする。云いか党れば，供試体が上 述の 1 循環を通過すれ刦衝撃值を 2 とするのであ る。ガス小焰による低温急熱は, 結果にはとんで影響 を与えないそ考兄られるので, 殊さらにこの抵抗值中 飞考慮しないととにした。急熱温度を $1150^{\circ} \mathrm{C}$ 飞選ん

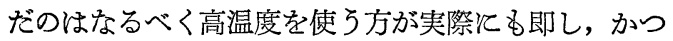
実験時間も短縮されると考学たためと，むら一つは既 報5) 飞述べたようと上記 3 成分中, 添加 $\mathrm{Fe}_{2} \mathrm{O}_{3}$ は大体 $1000^{\circ} \mathrm{C}$ を限界として，これょり高温では $\mathrm{MgO}$ 中r 熔解し，この温度以下では析出分離するための微構造 変化の影響を考兄たからである。また，これは既に判 明した微組織変化汇関してではあるが，他の諸生成化 合物による組織的な影響も急熱温度が高温になる程, 熱衝撃抵抗值とより良く現わされることとなり，得ら れる抵抗值は妥当なるのになる。急冷用の油は粘度の 低いるのであれば何でる良い訳であるが，著者はター ビン油を使用し，これを小型ニッケル坩堝（約 $30 \mathrm{cc}$ ） そみたし，この坩堝全体を大きな水槽中に吊して冷却 することとした。るちろん，水槽の水は攪拌機沉っ

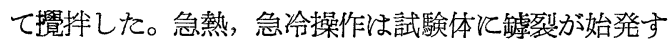
るまでではなく，少なくとも軽い指圧で割れるまで繰 返すことにした。このととは比較的速く微弱な罅裂が 入り，その後そのまま比較的に堅牢で熱衝撃抵抗の微 弱な躆裂が入り，その後そのまま比較的に堅牢で熱衝 撃抵执の大きなるのがあったからである。実験值は比 較的近接值を得た供試体では 2 简の平均を，そうで ないものは数筒の平均を採り，結果を図形に集約して 表わした。

\section{II. 実験結果亡考察}

$\mathrm{M}$ 、系 $(\mathrm{CaO}$ 低混合率で $2.2 \%$ の場合) の実験結 果を第 1 図r， $\mathrm{M}_{\text {口 }}$ 系 ( $\mathrm{CaO}$ 高混合率 $4.1 \%$ の場合) のそれを第 2 図に示した。曲線に附した数字は上述に よる熱衝撃抵抗值である。な特，斜走実直線は既報に 述べた通り，クリンカー中含有する $\mathrm{MgO}$ 量が $87 \%$
そ $90 \%$ 含有する最低限界線であって,とれらの線内の すべての点はいずれる $\mathrm{MgO} 87 \%$ 以上，あるいは 90 \%以上を含有するクリンカーである。また，実験点密 度は他部分よりも $x, y$ 両軸側飞密にとってある。供試 体は注とんぞ急熱時よりる急冷時化壊するるのが多 い。実験結果を考察し，図形から判明する事象を列記 すると次のようである。

1) $\mathrm{M}$ 、系: $\mathrm{Fe}_{2} \mathrm{O}_{3}$ 量を一定とするとき, $\mathrm{SiO}_{2}$ 量 の増加は熱衝撃抵抗值飞影響を与兄ないが， $\mathrm{SiO}_{2}$ 量 を定量として $\mathrm{Fe}_{2} \mathrm{O}_{3}$ を増加するときは抵抗性は不良 となる。

2） $\mathrm{M}_{\text {口 }}$ 系: $\mathrm{Fe}_{2} \mathrm{O}_{3}$ 量を一定として $\mathrm{SiO}_{2}$ 量を増加 する場合, $\mathrm{SiO}_{2}$ 量を一定にして $\mathrm{Fe}_{2} \mathrm{O}_{3}$ 量を増加する

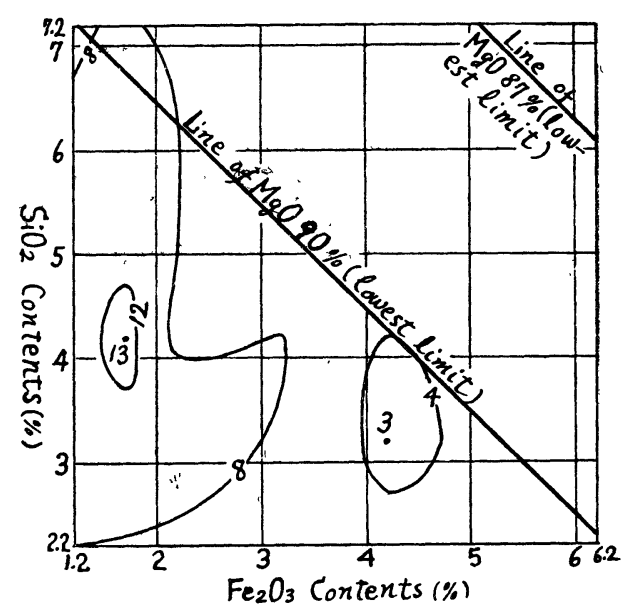

Numerals on the curves showing the number of times by rapidly heated and cooled

Fig. 1 M, System. (Firing temp. $1500^{\circ} \mathrm{C}$ ) ( $\mathrm{CaO}$ contents $2.2 \%$ )

Spalling resistance curves

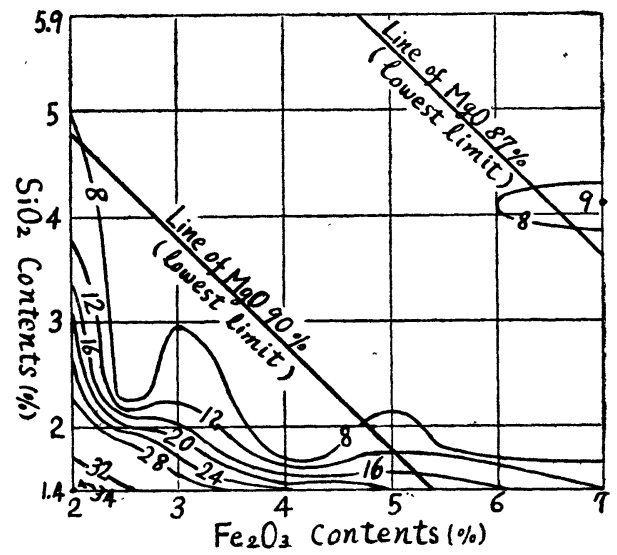

Numerals on the curves showing the number of times by rapidly heated and cooled

Fig. $2 \quad M_{\square}$ System. (Firing temp. $1500^{\circ} \mathrm{C}$ ) ( $\mathrm{CaO}$ contents $4.1 \%)$

Spalling resistance curves 
場合, 扔よび $\mathrm{Fe}_{2} \mathrm{O}_{3}, \mathrm{SiO}_{2}$ 量を共飞增加した場合は 共飞熱畺撃抵抗は弱くなる。云いかえれば，この系で は $\mathrm{Fe}_{2} \mathrm{O}_{3}$ も $\mathrm{SiO}_{2}$ る少量な程抵抗值は大きくなる。

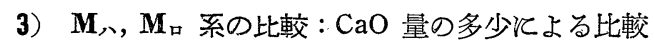
であるが，両図形から明らかなようと $\mathrm{CaO}$ 量と対す る系統的関係は存在しないが,ただ $\mathrm{CaO}$ 量の多い $\mathrm{M}_{\text {口 }}$ 系で耐急熱急冷のいちがるしく大きい区域が存在する ことが知られる。すなわち, 熱衝撃抵抗阔する限り $\mathrm{CaO}$ の含有量の多い原鉱石は決して捨てるべきるの ではない。

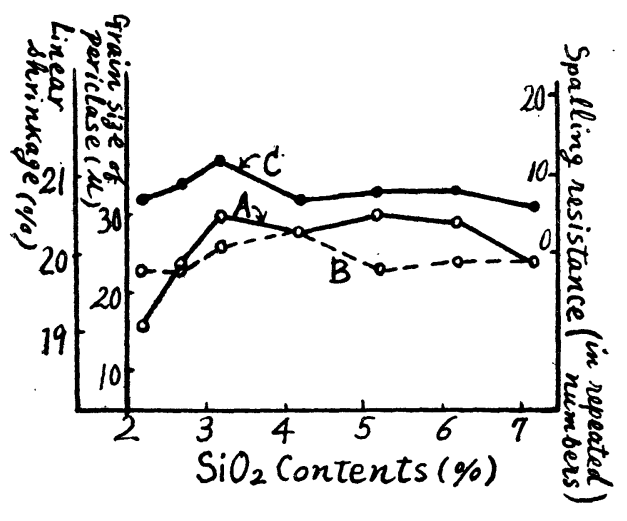

Relation among linear shrinkage (A Curve) and periclase grain size (B Curve) and Spalling resistance (C Curve).

$$
\left[\begin{array}{ll}
\mathrm{Fe}_{2} \mathrm{O}_{3} & \text { Content } 2.2 \% \\
\hline \mathrm{CaO} & \text { Content } 2.2 \%
\end{array}\right]
$$

Fig. 3 M, System. $\left(1500^{\circ} \mathrm{C}\right)$
4）熱衝撃抵抗と線收縮率，MgO 結晶の大きさの 関係：既報》飞述べたクリンカーの線収縮率と前報 ${ }^{11}$ に述べた $\mathrm{MgO}$ 結晶の大きさ,先の他の微構造との間 飞如何なる関係があるかを検討する必要がある。既 報3) 第 1,2 図, 前報1) 第 1,2 図と本報第 1,2 図を対比 し，例えば任意の部分を選べば第 3〜6 図のよ 5であ る。すなわち，熱衝撃抵抗性とこれらの諸事象との間 に表面的にはなんらの関係も今のところ認められな い。さて，熱衝撃抵抗性を直接決定するるのは，その 焼成体の物理性と物理的強度であるが, さらにこの物

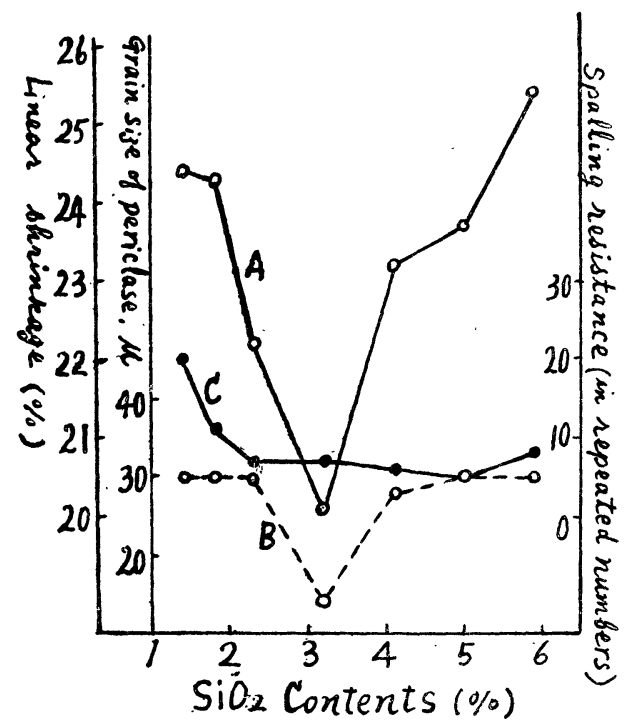

Relation among linear shrinkage (A Curve) and periclase grain size (B Curve) and Spalling resistance (C Curve).

$\left[\begin{array}{cc}\mathrm{Fe}_{2} \mathrm{O}_{3} & \text { Content } 5.0 \% \\ \hline \mathrm{CaO} \text { Content } 4.1 \%\end{array}\right]$

Fig. $5 \mathrm{M}_{\square}$ System. $\left(1500^{\circ} \mathrm{C}\right)$

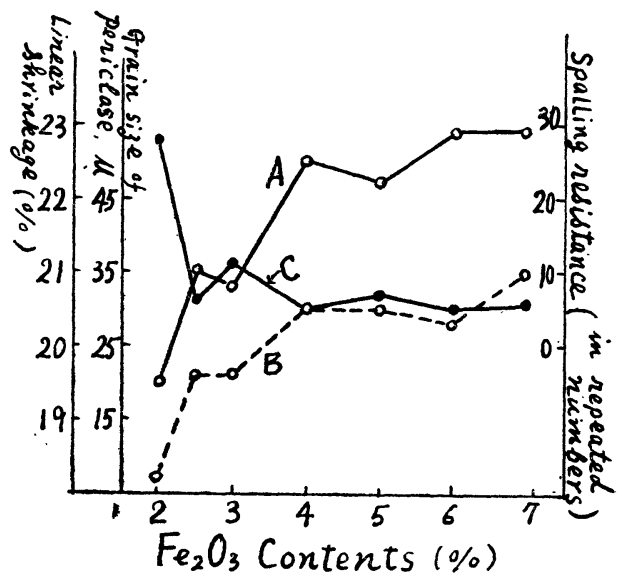

The Same as above relation. $\left[\begin{array}{ll}\mathrm{SiO}_{2} \text { Content } & 2.5 \% \\ \hline \mathrm{CaO} \text { Content } & 4.1 \%\end{array}\right]$

Fig. $6 \mathrm{M}_{\square}$ System. $\left(1500^{\circ} \mathrm{C}\right)$

Fig. $4 \quad \mathrm{M}$, System. $\left(1500^{\circ} \mathrm{C}\right)$ 
理的諸因子を決定する因子には種々あると考觉る。す なわち, その重要な一部を担当するのはクリンカー内 の微構造を相的に定める化学成分的不純物の存在とそ の量である。すなわち, 実験手段による物理的因子を 除けばこれらの不純物と MgO 間と生ずる諸相が微構 造を決定し，乙の微構造と $\mathrm{MgO}$ 結晶固有の特性が耐 急熱急冷性を定めることになる。したがって熱衝撃抵 抗性はその化学組成に大きな関係があり，また同じ組 成でも焼成温度によって相違することになる。上記の 実験は焼成温度 $1500^{\circ} \mathrm{C}$ のるのとついての測定值であ るから, 焼成温度による相違は不明であり, 結果は断 片的であるが，ここに求められた現象中で影著な点を 考える。

まず, $\mathrm{CaO}$ 量の多少とかかわらず $\mathrm{Fe}_{2} \mathrm{O}_{3}$ の增加は その少ない場合よりるクリンカーの耐熱衝撃性を不良 化する。すなわち, この点が前報に述べた酎消化性の 改善と逆行する。この点は現今一般提唱されてい る $\mathrm{Fe}_{2} \mathrm{O}_{3}$ を鉱化剮として使用する場合の一大欠点を なするのである。この原因種々存在するであろう が, 既報らで詳述した現象, すなわち $1000^{\circ} \mathrm{C}$ を境界 とする $\mathrm{Fe}_{2} \mathrm{O}_{3}$ の対 $\mathrm{MgO}$ 溶解析出の状態変化の影響 もその一部をなするのと考光る。すなわち, 温度の急 変によってペリクレーズ内部にこの現象が起り，十分 安定状態をとることができないためと考兄られる。こ の $\mathrm{Fe}_{2} \mathrm{O}_{3}$ の添加が熱衝撃抵抗值を低下させる事実は前 述の近藤・吉田の報告 ${ }^{2}$ 飞も示されていて, $\mathrm{Fe}_{2} \mathrm{O}_{3}$ の みを鉱化倣として使用する場合の宿命的欠陥のようで ある。次に $\mathrm{CaO}$ 量に関してはその含有量の比較的に 多いクリンカーが, 含有量の少ないるのより熱衝撃抵 抗の非常に良好な領域があり, 上記の 3 成分中, $\mathrm{CaO}$ だけを比較的多くして $\mathrm{SiO}_{2}, \mathrm{Fe}_{2} \mathrm{O}_{3}$ を共飞少なくす れば熱衝撃だけて対し（他の性質については別問題で ある）て比較的安定なクリンカーが得られるとととな る。これらの事象は明らかママグネシア・クリンカー の熱衝撃抵抗性が $\mathrm{MgO}$ の特有な物理的性㥽によるぼ かりでなく, その含まれる化学的夾雑成分と密接関 連し, しかもこの調節によって相当広範囲にクリンカ
一の該抵抗性を変化することができるるのと云光る。

総括

マグネシア・クリンカーと関する基礎的研究の一環 としてマグネシサイト軽焼物に $\mathrm{CaO}, \mathrm{SiO}_{2}$, 物よび $\mathrm{Fe}_{2} \mathrm{O}_{3}$ の 3 成分を任意的飞適当範囲内変量添加し, $1500^{\circ} \mathrm{C}$ 飞焼成して得たクリンカーマついて, その耐急 熱, 急冷性を検討した。試験法は電気炉一油中に急熱 急冷を繰返して, 試料が破壊しきると至るまでの回数 を求め，それを 2 種の図形集約した結果を要約すれ ば次のようである。

(i) $\mathrm{Fe}_{2} \mathrm{O}_{3}$ 量の増加は耐熱衝撃抵抗性を不良化する。 この現象は $\mathrm{CaO}$ 量の多少とかかわらず生起するが, この不良化の一部の原因に対しては添加 $\mathrm{Fe}_{2} \mathrm{O}_{3}$ の状態 変化によるものと考察を与えた(既報 $\left.{ }^{5}\right)$ 。

(ii) $\mathrm{SiO}_{2}$ 量の増加は, $\mathrm{CaO}$ 量が比較的に少ない場 合は無影響であるが, 多い場合は耐熱衝撃性を恵化す る。

(iii) $\mathrm{CaO}$ 量の増加はある箟囲で熱衝撃に対して非 常飞強いクリンカーを生ずる。すなわち, $\mathrm{CaO}$ 含有量 の多いマグネサイトの利用可能性を瞕示する。ただ 乙, この場合は $\mathrm{Fe}_{2} \mathrm{O}_{3}$ 並びに $\mathrm{SiO}_{2}$ の単独あるいは 両者增量と共に急激にこの抵抗性を悪化する。

(iv) マグネシア・クリンカーの耐急熱急冷性はMgO 結晶特有の物理性によるのみでなく, 副成分的化学成 分の存在条件によっていちぢるしく影響される。乙た がって, マグネシア耐火物の耐熱衝撃抵抁性は副成分 である $\mathrm{CaO}, \mathrm{SiO}_{2}, \mathrm{Fe}_{2} \mathrm{O}_{3}$ などの変量によって相当広 範囲変化調節するととできる。

\section{交献}

1）著者, 嚜協, 62 [700] 599 (1954)

2）近藤・吉田，弿協， 47131 (1939)

3) 著者, 千葉大学工学部研究報告, 3, 5, 76-87 (1952)

4）著者，害協，58 [654] 426 (1950)

5）著者，弿協，60 [667] 17 (1952)

(12/3/53 受付)

\section{お 知 ら せ \\ 輓近ガラスエ学の発展A5判160頁定佂250 円}

本書は W.E.S. Turner 教授の古稀を祝って Society of Glass Technology から Glass and W.E.S. Turner として記念出版されたもので, 本会が翻訳権を得て, 旭硝子, 日本板硝子両社の授助によって刊行されたもので ある。Turner 教授を中心に記述されているが, 最近 30 年のガラス工学界の進歩を簡潔とまてめられたものであ る。希望者は協会宛和申込みを乞う。 